\title{
Missional theological curricula and institutions
}

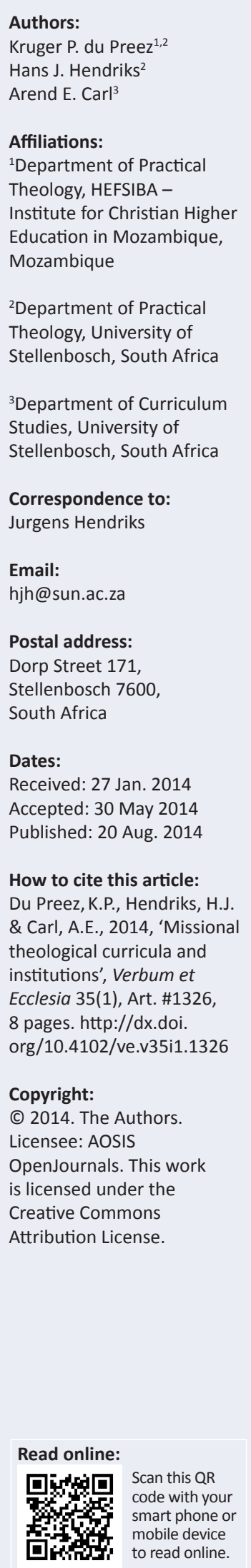

The article argues in favour of an all-embracing missional framework for curriculum development for theological institutions. When the curriculum of a subject such as ecclesiology has a missional hermeneutic, it will naturally lead to missional congregations. The authors use issues raised by the Network for African Congregational Theology (NetACT) institutions and the decisions of the Third Lausanne Congress in Cape Town (2010) as reference points in this article. They argue for a broad understanding of the concept 'missional' and are of the opinion that curricula that are integrative, normative, contextual and missional will lead to spiritual maturity and will result in a positive impact on church and society as a whole. The missio Dei as the work of the Trinitarian God is seen as being God's initiative. The incarnational model of Jesus Christ forms the basis for a theology and missiology where humility, vulnerability and servanthood play a pivotal role in curricula. An appeal is made for holistic missions with a strong emphasis on social engagement and the inclusion of community development. The Holy Spirit is seen as the empowering presence of the missio Dei, and the role of pneumatology in missional curriculum development is underscored. Theological institutes should become 'proclamation' institutions. Curricula should be ecumenical by nature and should include reaching the unreached and unengaged people groups. Theological education by extension is presented as an alternative way of decentralised theological education.

Intradisciplinary and/or interdisciplinary implications: The article calls for theology to be done with a missional hermeneutic, both intradisciplinarily and interdisciplinarily. The article involves theology and education and calls for all disciplines dealing with community development to collaborate.

\section{Missional curricula lead to missional congregations}

The authors of this article, who are all lecturers, share the emphasis of Charles Habib Malik, the former president of the UN General Assembly, on the importance of universities or institutions for Higher Education. In his 1981 Pascal Lectures, A Christian Critique of the University, he said (Cape Town Commitment 2011:30):

The university is a clear-cut fulcrum with which to move the world. The Church can render no greater service to itself and to the cause of the gospel than to try to recapture the universities for Christ. More potently than by any other means; change the university and you change the world. (p. 30)

In the context of this article, the authors are of the opinion that if one can effectively change theological institutions to be truly missional, the impact in sub-Saharan Africa will be notable.

The logic that missionally orientated theological institutions will eventually lead to missional congregations may seem like an oversimplification, but the authors share the opinion that, in general, their view hold true even though it takes time for congregational identity to change. The assumption is that if theological institutions and congregations and their leaders are directed towards themselves, they will eventually languish.

It is indeed unfortunate, but it has to be said that some theological institutions, their curricula and their models of training pastors are often stumbling blocks for church growth. It seems obvious that to prepare leaders for missional congregations, the curricula should be missional by nature, dedicating ample time to the witnessing task of the church and to involvement in other spheres outside of the comfortable borders of the congregation or institution. To prepare leaders for missional congregations, the thrust and ethos of the institutions should be missional. In the original research on which this article is based, Du Preez stated (2013):

The aim of this research is to empower staff to develop a curriculum framework in which all the theological institutions of NetACT will be able to develop their own relevant curricula that will be integrative, normative, missional and contextual and that will enhance high academic standards and lead to spiritual maturity. (p. 23) 


\section{The Third Lausanne Congress on World Evangelism}

The authors regard the booklet, The Cape Town Commitment: A confession of faith and a call to action, (2011:9-30), and the special section, Theological Education and Mission, as important in the argument for missional curricula. According to our knowledge, the call for missional curricula has not yet been taken up scientifically by theological institutions in sub-Saharan Africa. This article serves as an attempt to adhere to this call and to motivate institutions to follow an all-embracive, missional, curriculum approach. The booklet (The Cape Town Commitment 2011:52) states that theological education should be intrinsically missional '... since its place within the academy is not an end in itself, but to serve the mission of the Church in the world'. According to this declaration, theological education should stand in partnership with all forms of missional engagement. It then calls on all theological institutions to redesign their curricula to be more missional (The Cape Town Commitment 2011):

We urge that institutions and programs of theological education conduct a 'missional audit' of their curricula, structures and ethos, to ensure that they truly serve the needs and opportunities facing the Church in their cultures. (p. 52)

This congress brought together 4200 leaders from 198 countries and extended to hundreds of thousands more participating in meetings around the world and online. In their preface to the booklet (The Cape Town Commitment 2011:5), S Douglas Birdsall, the Executive Chairman, and Lindsay Brown, the International Director, state the following as their goal:

To bring a fresh challenge to the global Church to bear witness to Jesus Christ and all his teachings - in every nation, in every sphere of society, and in the realm of ideas. (p. 5)

We intend to use the issues raised by the NetACT institutions and the content of the Confession of Faith and Call of Action (The Cape Town Commitment 2011:9-30) by the Third Lausanne Congress on World Evangelism as reference points in this article. We argue for a broad understanding of the concept 'missional' and are of the conviction that curricula that are integrative, normative, contextual but also missional will lead to maturity and will result in a positive impact on the church and the society as a whole.

After the Third Congress on World Evangelism in Cape Town in 2010, a Lausanne theological training committee was appointed. It was given the responsibility to organise, together with the World Reformed Fellowship and the management of the International Council of Evangelical Theological Education (ICETE) and the World Evangelical Alliance (WEA), an international consultation on theological education. This conference took place at the Gordon-Conwell Theological Seminary in Boston, USA, during the first week of June 2012. Sixty-three rectors and senior academics from 31 countries took part to discuss contemporary global needs and trends and to consider new ways of possible cooperation.
Dr Flip Buys from the Reformed Church in South Africa was invited as part of the executive of the World Reformed Fellowship (WRF). He sent us an unpublished report of his impressions and the matters on which the conference agreed. We reflect selectively on some of these: ${ }^{1}$

- According to this illustrious group, theological training is still often trapped in a 'Christianity' paradigm with the thought that all that is needed is to shepherd established churches whilst ignoring the immediate context of churches that has become the mission field. It is as if many churches and theological institutions are not aware of dwindling and dying churches, growing agnosticism and disbelief and the revival of spiritualism, occultism and even hostility towards Christ and the church. Many theological institutions continue to train in an inward-oriented thinking paradigm and are not preparing future leaders to reach outside of their comfort zones.

- Full-time residential theological institutions are becoming too expensive to be sustainable. Only a very small part of the gifted potential leaders of the church are receiving training. This is hindering church growth. This model of pastor training struggles all over the world to attract sustainable numbers of students for training. Very large and ancient seminaries and theological schools and universities in Europe and the USA are struggling and even closing their doors. New models for distance learning should be designed and implemented.

- The ethos of an educational institution should create an atmosphere for growth in godliness and the development of missional compassion and vision. A question that should for example be asked is: do the prayers on a campus reflect an inside-oriented vision and subtly stimulate a 'consumer mentality' amongst students or do their prayers breathe a true compassion for the more than 6000 population groups and more than one billion people in the world who have never heard the gospel?

- Insensitivity and a 'do not care' mentality towards poverty in theological training do not reflect the heart of the living God to the poor.

- No matter how important academic research, it may not be the highest priority for training institutions as this leads to an intellectual religion and turns out to be an obstacle for the missional growth of the church. The growth towards spiritual maturity and an increasing zeal to serve and to love the Lord and to serve others, as part of God's mission (missio Dei), should be the highest purpose of theological education.

In an attempt to address the above issues, some empirical research was done amongst NetACT-affiliated institutions.

\section{Empirical research on missional awareness}

Empirical research was done within 10 NetACT theological institutions of Reformed or Presbyterian tradition in Angola, Kenya, Malawi, Mozambique, Namibia, Zambia 1.For further information, the reader can browse the following URL: http://www. lausanne.org/en/multimedia/videos/theological-education-videos.html 
and Zimbabwe. Through the distribution of questionnaires at curriculum development workshops, an attempt was inter alia made to establish the missional awareness of the different NetACT institutions and to establish to what extent such awareness is reflected in their curricula.

The following main conclusions were drawn from the questionnaires regarding a missional approach by NetACT institutions:

- Though the institutions are in favour of a holistic missional approach as an integral part of their curricula, they admit that their curricula cannot be described as missionally orientated.

- Institutions do not regard their campuses as centres for reaching the community.

- Much more can be done to include studies on the unreached people groups.

- Community development forms part of the majority of the curricula.

- Practical work of students in churches and communities is receiving due attention.

- The study of traditional religions in Africa and the planting of new churches or congregations are high on the priority list of the institutions.

In the argument for an all-embracing missional curriculum, missiology as discipline plays an important role. According to Tennent (2010:192), missiology is currently serving as the major source of the global theological renewal. Some concept clarifications related to missiology are, however, first needed.

\section{Concept clarification related to missiology as discipline}

The word missionary normally refers to a person who engages in missions, usually in a culture other than his or her own. We plead for a broader concept of the word missionary as including all members of a church with a witnessing zeal.

Missional theologians: Kritzinger, Meiring and Saayman (1994) talk about the need for well qualified missional orientated theologians:

The difficulties of the mission field, the intricate problems to be faced, the challenges of Bible translation, and reacting to the needs of young churches, all these call for well-qualified theologians, the best a church can make available. (p. 60)

A missional church: such a church places its commitment to participate in God's mission in the world at the centre of its life and ministry (Van Gelder 2008:267). The same can then be said of a missional theological institution. Mission is therefore not only an activity or part of a curriculum. Rather it should be at the centre of the institution's identity participating in the life of the Trinity (Van Gelder 2008:267).

The missiological focus of the Bible: to say that the Bible has a missiological focus and that everything is really 'all about mission' does not mean in this research that one tries to find something relevant to evangelism in every verse of the Bible. Rather, one refers to something deeper and wider in relation to the Bible as a whole that is missional by nature.

The concept missio Dei needs some more clarification. Missio Dei can literally be translated by 'the mission of God', which is in line with the main emphasis of this study. Mission is more about God and who he is than about us and what we do (Tennent 2010:55). Mission in this research refers in the first place to God's redemptive and historic initiative in this world, quite apart from any actions or tasks or strategies or initiatives that the church or individuals undertake. We consider as fundamentally sound the idea of understanding mission through the lens of the missio Dei, and we propose it as a framework for a sound curriculum. Following this line of thinking, a biblical missiology should be built on the foundation of a Trinitarian theology. Typically, it should be simultaneously God centred, Kingdom focused and church based. Church is more than the institution. Here it refers to the faith community being salt of the earth and light of the world as Keifert (2006) says:

The mission of God is far greater than the church, as the Reign of God is greater than the church; however, the mission of God needs a church, among many other institutions, to carry out God's mission. (p. 166)

\section{A Trinitarian missional hermeneutic}

According to David Bosch in his magnum opus, Transforming mission: Paradigm shifts in theology of missions (1991), the general approach to support missions included profusely quoting biblical texts rather than seeing the entire Bible as revealing the missionary nature of God in relationship to the world. From his perspective, all theology should be regarded as fundamentally missional because biblical theology reveals God as a missionary God. This approach is also echoed by Timothy Tennent in his book Invitation to world missions: A Trinitarian missiology for the twenty-first century (2010).

Instead of using just texts to provide a foundation for missions, Wright (2006:48) proposes what he calls a 'missional hermeneutics' that sees the whole of Scripture as a 'missional phenomenon' (Wright 2006:48). According to him, 'a missional basis of the Bible' (Wright 2006:62) becomes apparent only when one shifts one's paradigm of missions from an anthropocentric (or ecclesiocentric) conception to a radically theocentric worldview. Missions, therefore, arises not simply as a response of obedience to a command given to the church but as an invitation to participate with God in his redemptive work in the world. Kevin Vanhoozer calls this unfolding narrative a 'theodrama' or 'God's drama', which, he argues, is essentially missional, consisting of a series of historical entrances and exoduses like incarnation, crucifixion, resurrection, ascension and Pentecost (Vanhoozer 2006:110).

Trinitarian missiology serves as the foundation for an all-embracing missional curriculum of theological institutions. One therefore needs to explore this more. 


\section{God the Father: The source, initiator and telos of the missio Dei: Curriculum implications}

The liberating news that the source of mission is in the loving fatherly heart of God should be emphasised in curricula to eradicate perceptions that mission work originates from Western missionaries. To do mission work and evangelism is to reflect the missional heart and glory of God the Father and not to obey or please the church.

\section{God the Son: The incarnation of the missio Dei: Curriculum implications}

The incarnation model of Jesus should be 'embodied' and followed by theological institutions and should be the underscoring principle when writing curricula. Theological institutes should identify themselves with the concept of being 'missional institutions'.

Under the theme Walk in humility, rejecting the idolatry of power, the Cape Town Commitment (Lausanne Congress Third 2011:62) notes: 'In a world of greed, power and abuse, God is calling his Church to be the place of gentle humility and selfless love among its members.'

The model that the church and theological institutions should try to live up to is a model of humility and selfless love according to the incarnational model of Jesus. This leadership style should form the basis of the formal and the so-called 'hidden' curricula of theological institutions. The model for the practice of authority for the church is Jesus himself, whose authority was a paradoxical authority to the very last, an authority which in its unprotectedness and vulnerability turns any other type of authority upside down (Lohfink 1985:117).

Lecturers should teach and demonstrate to students that this servanthood lifestyle should extend to their ministries but also to their marriage and family lives as well as to their socioeconomic relationships. In this unprotected, vulnerable, servanthood style, missions should be done in a holistic way and curricula should reflect this.

\section{Holistic missions and holistic curricula}

The temptation to draw a distinction between 'evangelism' and 'social action' is, unfortunately, always lurking, given a strong pietistic and dualistic tendency in many churches and theological institutions in sub-Saharan Africa. The temptation to concentrate only on 'relief' work is in reality quite often an easy form of escapism. For this reason, it is perhaps proper to quote part of the statements of the 1974 Lausanne Covenant that dealt with exactly this problem (Lausanne Covenant 1974):

We affirm that evangelism and socio-political involvement are both part of our Christian duty ... The message of salvation implies also a message of judgment upon every form of alienation, oppression and discrimination, and we should not be afraid to denounce evil and injustice wherever they exist. When people receive Christ they are born again into his kingdom and must seek not only to exhibit but also to spread its righteousness in the midst of an unrighteous world. The salvation we claim should be transforming us in the totality of our personal and social responsibilities. Faith without works is dead. (n.p.)

The duty of the church and theological institutions to have a courageous prophetic voice in the face of injustices speaks for itself. The duty to sometimes confront authorities and even the government of the day is not addressed here but flows naturally from the holistic approach of doing missions.

There are three key features in Article 5 of the Lausanne Covenant that were quoted in part above and that deserve to be highlighted:

- Firstly, the Lausanne Covenant properly places social action within a theological context, linking it to the doctrines of God, reconciliation, righteousness and the fact that all men and women are created in the image of God.

- Secondly, the statement affirms that evangelism and social action are not 'mutually exclusive', thereby laying the groundwork for an integrated view of how the person and work of Christ are reflected in the life and witness of the church.

- Finally, at the heart of the statement is an expression of metanoia, or repentance, for the church's failure consistently to live according to the biblical witness to social action and the struggle for justice on behalf of the oppressed (Tennent 2010:393).

The world needs the full ministry of the church, the Word and the deeds if it is to 'hear' the gospel. Tite Tienou (as cited by Gustafson 1998) calls for an 'alive' evangelism to accompany social transformation:

Social transformation is part of the message of and a natural outgrowth of evangelism ... but it will likely not take place through a dead evangelism: Evangelism will likely not result in social transformation unless the church and Christian community witness by their lifestyles that they have been transformed. If we really mean business let us deflate our empty words and inflate out actions. (p. 132)

There should not be a dualism in the curriculum between pastoral work and social work. Community development should be an important subject. Students should be encouraged to use their prophetic voices diplomatically but also courageously as far as social and political injustices are concerned. They should be prophetic during their studies but especially as part of their later ministries.

\section{God the Holy Spirit: The empowering presence of the missio Dei}

The Cape Town Commitment (Lausanne Congress Third 2011) emphasises the importance of the guidance and power of the Holy Spirit in missions: 
Without the convicting work of the Spirit of Christ, our witness is in vain. Without the gifts, guidance and power of the Spirit, our mission is mere human effort. And without the fruit of the Spirit our unattractive lives cannot reflect the beauty of the gospel. (p. 15)

The theological institutes should see themselves not only as learning institutes but also as proclamation institutes under the guidance of the Holy Spirit. The work of the Holy Spirit should be an integrated part of not only systematic theology but also of missiology and congregational studies. Students should realise that their engagement in ministry and therefore in missions is pointless and fruitless without the presence, guidance and power of the Holy Spirit. This is true of missions in all its dimensions: evangelism, bearing witness to the truth, discipling, peace-making, social engagement, ethical transformation, caring for creation, overcoming evil powers, casting out demonic spirits, healing the sick, suffering and enduring under persecution (Lausanne Congress Third 2011:16).

One of the central duties of the Holy Spirit is to guide the church 'into all truth'. One can say that the Holy Spirit is the great teacher or catechist. The underdeveloped doctrine of the Holy Spirit and the lack of contextualisation have limited the church's ability to integrate missionary training with important biblical themes such as the role of persecution or the role of signs and wonders or the expulsion of demons in the proclamation of the gospel. Even a casual reading of the book of Acts reveals that signs and wonders, persecution and the expulsion of demons often accompany and attest to the faithful preaching of the gospel. Churches and theological institutions in sub-Saharan Africa are more aware of the latter but often fail to include these elements in their theological curricula. It is obvious that a missional curriculum should also be contextual.

A missional curriculum should be the natural outcome of a missionally driven church and, thus, a missional curriculum and a missional church are interdependent. The missional curriculum should envisage the characteristics of a missional ecclesiology.

\section{The need for a missional ecclesiology}

When one says 'missions', one also says 'church'. The church takes the Good News to the world. Ecclesiology should form an essential part of writing a missional framework for curriculum development.

In a missionally orientated church, believers can grow towards spiritual maturity. In missionally orientated theological seminaries, students can follow a relevant, globally focused, contextualised curriculum.

Within the Reformed tradition, ecclesiology, church history and church polity did not have a missio Dei hermeneutic. The purpose of this section is to explore the role of ecclesiology that lies at the heart of many of the most pressing issues in contemporary missiology. According to Tennent (2010:434), ecclesiology has lagged far behind other branches of theology in missionary writings. Keifert insists that a missional church should move beyond being just a spiritual gas station providing spiritual services. It should move beyond forming a tight knit Christian community. 'A missional church focuses on being mission, not just doing mission' (Keifert 2006:166).

There is a growing awareness that the local congregation should be the basic unit of the Christian witness. Guder (2000:145) defines the local congregation as '... the vital instrument for the fulfilment of the missionary vocation of the Church'. Coleman (1981) emphasises the fact that Christian disciples are sent men and women:

Evangelism is not an optional accessory to our life. It is the heartbeat of all that we are called to be and to do. It is the commission of the church which gives meaning to all else that is undertaken in the Name of Christ. (p. 74)

Public worship, especially on Sundays, should be seen as a gathering of the mission community and should be open and welcoming to all (Guder 2000:174). In public worship, there should be regular celebrations of calling and commissioning. The intercessory prayer of the congregation should not only be directed to missionaries in the trenches far away but should also support the congregation's 'local missionaries'. Within the gatherings of the congregations, their experiences, challenges, disappointments and blessings should be reported and learned from. The ancient sense of the conclusion of public worship as the sending out of God's people, ita, missa est [go, you are sent], should be translated into the concrete forms of congregational life. The existing concept of an 'active church member' should mean a missional one.

The solution then for formalism and nominalism is that every Christian community should see itself as a community of missionaries. The leadership's responsibility to this community is to guide them to identify God's calling, to recognise the gifts and opportunities they have, to provide the biblical and theological training to incarnate the gospel in their particular fields and then to commission them to that ministry. Our structures of membership need to be transformed into disciplines of sending (Guder 2000:178).

This biblical insight should not only form part of the curriculum of missiology, but it should also be the ponto de partida [the point of departure] of disciplines such as systematic theology, ecclesiology and practical theology in general. It should be clear that, generally speaking, the institutional church needs a mind and heart conversion to comply with the demands of being a missional church.

\section{The distinction between clergy or professionalism and laity should be abolished}

Conn (1979:311-363) shows that the Reformation rediscovered the nature of the church and denied, in principle, the 
distinction between clergy and laity. In practice, however, it did not happen because of professionalisation. According to Conn, Luther and Calvin failed to question radically the difference between the clergy and the laity.

The quite radical distinction between pastors and ordinary members is a reality in churches related to NetACT theological institutions. The role and status of missionaries kept the inequality in place. With independence, ordained national clerics maintained their professionalised role. Ultimately, leadership became defined not in terms of the service of gifts but in terms of salaried or non-salaried, ordained and unordained people. It led to a situation where a growing church was unable to financially support full-time clergy. The result in many parts of Africa was a hierarchy of unordained, academically ill-trained, poorly paid workers (Conn 1979:311-363).

The problem cannot be solved simply by ordaining those presently functioning as unordained pastors. Clericalism is not overcome by rejecting an ordained ministry or by downplaying its significance or task. The answer lies in training lay people to be missionaries '... in shops, villages, farms, cities, classrooms, homes, law offices, in counselling, politics, statecraft and recreation' (Burrows 1981:66).

If the church is to be missional, it follows that one should have a theology of laity. A theology of laity should break with the notion, so fundamental to the Enlightenment, that the private sphere of life should be separated from the public (Newbigin 1989:142). Moltmann (1975:11) says that the theology of the future should no longer only be a theology for priests and pastors but also for laity. He (Moltmann 1975) foresees that:

It will be directed not only towards divine service in the church, but also towards divine service in the everyday life of the world. Its practical implementation will include preaching and worship, pastoral duties and Christian community, but also socialization, democratization, education toward self-reliance and political life. (p. 11)

Students should constantly be reminded of what the church is, and they should be warned against an over-institutionalisation and a 'sinodocracy' where the synod or synodic committees have all the power to the detriment of the role of the local congregations and her members. The dangers of a culturally imprisoned church should be clear. Church polity should be written with the missional emphasis in mind.

In this process of becoming an incarnational, missional church, the place and duties of the ordinary members should be revisited. The theological education of the 'laity' should be the end-focus of all theological education.

\section{The possibility of decentralised theological education}

One possibility for renewal in the area of training laity may be with TEE. One of the great assets of the movement of theological training by extension lies in the fact that it has not been restricted to either a clergy-training program or a lay-training program. We propose TEE as a possible model to address the problem of traditional theological training as reflected above.

TEE is a ministry-oriented model of church-leadership training, the primary purpose of which is to provide training for people who normally are already serving in church-leadership positions. Mulholland (1976:66) called it 'decentralized theological education'. And further: 'It is a field-based approach which does not interrupt the learner's productive relationship to society.' TEE is distinguished from traditional models of leadership training by several factors of which the most obvious one is the 'extension' element. As an extension program, the training is offered at a location near the student's home, eliminating the need to spend months or years in preparation at a Bible school or seminary. One of the main visions of the TEE model is '... to encourage and enable local leaders to develop their gifts and ministries without leaving their homes, jobs, communities, and local congregations' (Kinsler 1981:30). TEE is a flexible programme that is able to adjust to the needs and abilities of the students and can be developed and adapted to the local situation. Any program of this nature should be missional by nature.

The Gereformeerde Zendings Bond (GZB), the Reformed mission organisation from the Netherlands, signed an agreement with HEFSIBA ICHE in Mozambique in 2010. Their representative for TEE training, the Rev. Joram Oudshoorn, would dedicate $50 \%$ of his time to TEE training in the different congregations of the Reformed Church in Mozambique in the Mphatso Synod, and 50\% would be dedicated to the training of students at HEFSIBA in missiology and in the TEE material and approach. The finalyear students are also doing their practical work with the Rev. Oudshoorn. This opens the possibility to integrate the TEE ethos and material into the curriculum of the theological institution.

The advantage of TEE is, according to Kinsler (1981:194), that it reaches out to the poor who '... could never attend a traditional seminary'.

A danger with programs such as TEE is that members may not be exposed to the rest of the Body of Christ. Ecumenism should thus form an integral part of the missional curriculum.

\section{The church and ecumenical relations}

The High Priest prayer of Jesus in John 17:22-23 should serve as the rationale for ecumenical relations:

I gave them the same glory you gave me, so that they may be one, just as you and I are one: I in them and you in me, so that the world may know that you sent me and that you love them as you love me. (Good News Bible) 
In line with this, Durand (1961) wrote:

The glory of Christ is not a passive and latent power of the Spirit, but it is active and should become a visible expression. Through the unified visual evidence and life of the church, the world will be brought to the discovery that the origin of this unity is Christ himself, the Sent of the Father. Thus the unity as the essential characteristic of the church, should serve the coming of the Kingdom. (p. 37, authors' own translation)

We are aware of different interpretations of ecumenism that can broadly be categorised as fundamental ecumenicity, evangelical ecumenicity, World Council of Churches (WCC) ecumenicity and the so called religious ecumenicity. Without entering into this debate, we can identify with the following quote by S. Michael Hoadmann (n.d.):

The ultimate goal is God's glory and the evangelism and discipleship of the lost. The ecumenical venture must be structured in this way. Thus, those we join with must believe the biblical definition of the gospel and they must also be about seeking the same goal of God's glory and the salvation of the lost. (n.p.)

The fact of the matter is that the church and theological institutions should be aware of the 'global body of Christ'. A spirit of denominationalism should make way for a spirit of cooperation and ecumenism as a joint mission strategy. The Cape Town Commitment (Lausanne Congress Third 2011:65, 66) confirms this by stating that a divided church has no message for a divided world and that the failure of the church to live in reconciled unity is a major obstacle to authenticity and effectiveness in mission. Curricula should help future African pastors to welcome partners in their mission endeavours.

Theological institutions should therefore be exposed to ecumenical relations by attending the services and conferences of other denominations. A missional 'audit' should be made to see if ecumenical relations and the unity of the body of Christ are reflected in the curriculum. Strong emphasis should be on joint missional endeavours, opening the horizons of the students even beyond the borders of their own denomination, country and continent.

\section{The unreached people groups and oral communication}

'The heart of God longs that all people have access to the knowledge of God's love and of his saving work through Jesus Christ' (Lausanne Congress Third 2011:53). Part and parcel of a missional framework for the NetACT institutions should include unreached and unengaged people.

When the curricula of theological institutions address the need of unreached and unengaged people, when students learn to look further than their own cultural and religious borders, they will be able to grow into spiritual maturity.

Theological institutions should also take cognisance that the majority of the world's population are oral communicators who cannot or do not learn through literate means. More than $50 \%$ of oral communicators are unreached. It is estimated that approximately 350 million people are left without a single verse of Scripture in their language. In addition to the 'primary oral learners', there are many 'secondary learners' who are technically literate but prefer to communicate in an oral manner with the rise of visual learning and the dominance of images in communication (Lausanne Congress Third 2011:55).

Reaching the unreached should not only be imprinted on the minds of students through the curricula and reference to literature but also through outreaches. Unreached people groups in specific countries should be identified, prayed for and evangelised. In this process, the translation of the Bible into the languages of peoples who do not possess the whole Bible in their mother tongue should be encouraged. Students should receive training in translation principles so as to be able to help with the translation of the Bible, booklets and pamphlets.

If the theological institutions of NetACT would agree to have missionally driven curricula, the reaching of the unreached and unengaged people groups in at least their countries should get a prominent place.

\section{Conclusion}

In short, the answer to the question, 'Why should an institution and its curriculum be missional?', is simply because it is biblical, because it reflects the Trinitarian heart of God and because it is relevant and all-embracing ( Du Preez 2013:130).

In NetACT's Studying congregations in Africa (Hendriks 2004:24-25), it is stated that God should be seen as a Trinity and a missional God. It concludes that, since identity is derived from one's faith in this triune and missional God, the implication is that the anthropology and ecclesiology of the church and its institutions should have a profound missional basis. Referring to Korten (1995), the centrality of Jesus Christ as well as the emphasis on the poor and marginalised people are stated:

Jesus' life and teaching tell us that the Kingdom of God is approaching and that it brings salvation for all, especially the poor, the weak, the outcasts, the unjust and sinners. (p. 1)

Little research and work has been done to guide theological lecturers as curriculum developers of the theological institutions and to do so within a missional framework. This article tried to help in this regard.

We close with the appeal of the Third Lausanne Congress on World Evangelism (Lausanne Congress Third 2011) and the special section, Theological Education and Mission:

We urge that institutions and programs of theological education conduct a 'missional audit' of their curricula, structures and ethos, to ensure that they truly serve the needs and opportunities facing the Church in their cultures. (n.p.) 


\section{Acknowledgements Competing interests}

The authors declare that they have no financial or personal relationship(s) that may have inappropriately influenced them in writing this article.

\section{Authors' contributions}

The article is based on the doctoral dissertation of K.P.d.P. (HEFSIBA - Institute for Christian Higher Education in Mozambique) whilst H.J.H. (Stellenbosch University) and A.E.C. (Stellenbosch University) were the promoters.

\section{References}

Bosch, D.J., 1991, Transforming mission: Paradigm shifts in theology of mission, Orbis Books, Maryknoll, NY.

Burrows, W.R., 1981, New ministries: The global context, Orbis Books, Maryknoll, NY.

Cape Town Commitment: A confession of faith and a call to action, 2011, Third Lausanne Congress, Bodmin, Printbridge.

Coleman, R.E., 1981, 'The master's plan', in R.D. Winter \& S.C. Hawthorne (eds.) Perspectives on the world movement, pp. 70-74, William Carey Library, Pasadena, CA.

Conn, H.M., 1979, 'Theological education and the search for excellence', Westminster Theological Journal 41, 311-363.

Du Preez, K.P., 2013, 'Curriculum development in theological institutions of the reformed tradition in sub-Saharan Africa', PhD dissertation, Department of Practical Theology, Stellenbosch University, viewed 17 March 2014, from http:// scholar.sun.ac.za/handle/10019.1/80047

Durand, J.J.F., 1961, Una sancta catholica in sendingperspektief, W ten Have, Amsterdam.

Guder, D.L., 2000, The continuing conversion of the church, William. B. Eerdmans Publishing Company, Grand Rapids, MI.
Gustafson, J.W., 1998, 'The integration of development and evangelism missiology', An International Review 26(2), 131-142.

Hendriks, H.J., 2004, Studying congregations in Africa, Lux Verbi, Wellington.

Hoadmann, S., n.d., 'Michael', viewed 01 April 2014, from http://www.gotquestions. org/ecumenism-ecumenical.html

Keifert, P.R., 2006, We are here now: A new missional era. A missional journey of spiritual discovery, Allelon Publishing, Eagle, ID.

Kinsler, R.F., 1981, The extension movement in theological education, William Carey Library, Pasadena.

Korten, D.C., 1995, When corporations rule the world, Kumarian, West Hartford.

Kritzinger, J.J., Meiring, P.G.J. \& Saayman, W.A., 1994, On being witnesses. What is the goal and content of mission; Who is responsible for mission; The context of mission; The methods of mission, Orion Publishers, Johannesburg.

Laussane Covenant, 1974, viewed 24 November 2012, from http:www.lausanne.org / Lausanne-1974/ Lausanne-covenant. html

Laussanne Congress Third, 2011, The Cape Town Commitment: A confession of faith and a call to action, Printbridge, Bodmin, UK.

Laussane Movement, n.d., 'Website for theological education', viewed 24 November 2012, from www.lausanne.org/en/multimedia/videos/theological-educationvideos.html www.youtube.com/watch?v= FiK5hXKq Uko

Lohfink, G., 1985, Jesus and community: The social dimension of Christian faith, transl. J.P. Galvin, University of Pennsylvania Press, Philadelphia.

Moltmann, J., 1975, The church in the power of the Spirit, SCM, London.

Mulholland, K.B. 1976, Adventures in training the ministry, Presbyterian and Reformed Publishing Company, Nutley, NJ.

Newbigin, L., 1989, The Gospel in a pluralist society, William. B. Eerdmans Publishing Company, Grand Rapids.

Tennent, T.C., 2010, Invitation to world missions: A Trinitarian missiology for the twenty-first century, Kregel, Grand Rapids, MI.

Van Gelder, C. (ed.), 2008, The missional church and denominations: Helping congregations develop a missional identity, William. B. Eerdmans Publishing Company, Grand Rapids, MI, MI.

Vanhoozer, K.J., 2006, 'One rule to rule them all?. Theological method in an era of world Christianity', in H. Netland \& G. Ott (eds.), Global theologizing, pp. 18-126, Baker Academic, Grand Rapids.

Wright, C.J.H., 2006, The mission of God: Unlocking the Bible's grand narrative, IVP Academic, Grand Rapids. 